\title{
THE EFFECT OF FEED ADDITIVE CONTAINING VITAMINS AND TRACE ELEMENTS ON THE ELEMENTS PROFILE AND GROWTH OF SKIN DERIVATIVES IN HORSES*
}

\author{
Petra Jančíková, Pavel Horký, Ladis lav Zeman \\ Department of Animal Nutrition and Forage Production, Faculty of Agronomy, Mendel University \\ in Brno, Zemedelska 1, 61300 Brno, Czech Republic
}

\begin{abstract}
An important role of nutritional supplements in the quality and growth of skin derivatives is not sufficiently explored. The aim of our experiment was to recognize how the application of selected vitamins and an organic source of zinc and copper affects the growth and elemental content of hooves and hairs. Sixteen warm-blooded horses were divided into two groups. Both groups received the same basic feeding ration, which was enriched with a feed additive for the experimental group. The contents of individual elements in hoof and hair samples were established using the atomic absorption spectrometry method. Samples from the experimental group of horses showed a significantly increased amount of zinc $(P<0.01)$, copper and manganese $(P<0.05)$ deposited in the hoof and a significantly decreased $(P<0.05)$ amount of manganese, iron, and calcium deposited in the hair after nine months of monitoring. Differences between initial and final samples of hooves and hair were insignificant in the control group. The growth rate of hair and hoof wall was significantly higher $(\mathrm{P}<0.01)$ in horses from the experimental group than from the control one. Horses receiving the feed additive achieved a faster growth of the hoof horn with an adequate quality of hooves in our experiment. The experiment shows that the hair is not a reliable indicator of nutritional status of horses. However, assessing the impact of individual vitamins and trace elements, or the impact of various sources of trace elements on the elements profile and growth rate of skin derivatives of horses should be subject to further observation.
\end{abstract}

Key words: horse, vitamin, zinc and copper, hoof, hair

While the horny substance of the hoof is a dynamic tissue, only an adequate and good-quality nutrition results in the continual growth and high quality of hooves (Abdin-Bey, 2007). Nutrients required for normal keratinization and good hoof horn

\footnotetext{
*This work has been realized in the context of grant IP 9/2010 and TP 2/2011, financed by the Internal Grant Agency (IGA) of Faculty of Agronomy, Mendel University in Brno, Czech Republic.
} 
quality are amino acids, especially sulphur-containing amino acids such as cysteine or methionine, minerals and trace elements, in particular zinc, and vitamins like biotin (Tomlinson et al., 2004). Zinc plays a key role in the proliferation of epidermal cells and in the formation of the structural proteins during the keratinization process (Tenaud et al., 2000). The keratinizing epidermal cells produce the intercellular cementing substance consisting of glycoprotein and lipid complex such as phospholipids, glycolipids and acylglycosylceramides. Their main function is to establish cell to cell adhesion providing mechanical stability to the horn (Mülling and Budras, 1998). Copper and zinc are component parts of superoxide dismutase, an enzyme that prevents lipid peroxidation and other damage to cells and tissues (Wagner et al., 2010). Protection of the intercellular cementing substance is critical in maintenance of the structural integrity and biological function of the horn (Mülling et al., 1999). Biotin is a vitamin of crucial significance in the development of the horny tissue and positively affects its compactness and integrity (Mülling, 2009). The aim of our experiment was to determine the effects of the application of vitamin-mineral premix on the quality and growth of skin derivatives in horses.

\section{Material and methods}

Sixteen Bohemian warm-blooded horses were gradually included in the experiment for 9 months. The horses were stabled in box stalls (of similar dimensions) with a feeding pump, and had access to an outdoor pen or walker. The horses of diverse age (5-19 years; the average age of horses from the control group 12.0 \pm 5.0 years; mares from the experimental group $7.5 \pm 2.9$ years) and sex (15 mares and 1 gelding), similar weight class (520-580 kg) and light workload were divided into two groups, subjected to different nutrition (Table 1). Five months before and during the experiment, the animals received the same basic feeding rations, which represented $11.5 \mathrm{~kg}$ of hay, $1.0 \mathrm{~kg}$ of ground oats, $0.75 \mathrm{~kg}$ of wheat meal and $0.75 \mathrm{~kg}$ barley meal. Licks containing only common salt were available throughout the entire experimental period. The intake of zinc and copper in both groups was calculated from feed analyses (Table 2). The control group $(\mathrm{n}=8)$ received $340 \mathrm{mg} \mathrm{Zn/day/horse} \mathrm{and} 64$ $\mathrm{mg} \mathrm{Cu} /$ day/horse from the basic feeding ration. On top of that, horses in the experimental group $(\mathrm{n}=8)$ were fed with the feed additive (Table 3$)$ at $10 \mathrm{~g} /$ day. The total daily intake of zinc and copper by horses in this group was 440 and $84 \mathrm{mg} / \mathrm{horse}$, respectively, which are the values corresponding to the recommended daily intake of trace elements (NRC, 2007). Sources of zinc and copper were organic forms of these elements (complex of amino acids n-hydrate). The amount of mineral substances in water was not taken into account.

On the first day and after 9 months of the experiment, hoof horn and mane hair were sampled in the horses. On the 70th day of the experiment, hoof horn was sampled in the horses and further three samplings followed during the next 70 days. On the 140th day of the experiment, mane hair was sampled in the horses and fur- 
ther two samplings followed during the next 70 days. Trimming of the hooves was the same before and during the experiment. Prior to the sampling, the hooves were thoroughly cleaned. The horn itself was scraped using a shoe-rasp and collected in sampling containers. The samples were taken both from the hoof sole surface and from the hoof-wall of chest limbs. The recess was rasped right beneath the coronet fornix in all horses in order to monitor the hoof-wall increment for a certain period. The tape measure was placed to the hoof, and it was photographed in detail. Growth rate of the hoof-wall was assessed by comparing the images. A piece of mane hair was removed from the nape in horses and the other samples were obtained from the same place within the experimental periods. The hair increment was measured by means of a ruler. A homogeneous sample charge of $0.5 \mathrm{~g}$ was mineralized in the mixture of concentrated nitric acid and hydrogen peroxide in the Ethos 1 microwave system (Milestone, Italy). After the sample decomposition, the solution of demineralized water was added to achieve the volume of 25 $\mathrm{ml}$. The concentration of elements in solutions prepared in this way was established on the atomic absorption spectrometer with a continual radiation source of high resolution Model Contr AA 700 (Analytik Jena, Germany). Wavelengths used were as follows: $\mathrm{Zn} 213.857 \mathrm{~nm}, \mathrm{Fe} 248.327 \mathrm{~nm}, \mathrm{Cu} 324.754 \mathrm{~nm}$ and $\mathrm{Ca}$ $422.673 \mathrm{~nm}$.

Table 1. The characteristic of horses and conditions under which the horses were kept

\begin{tabular}{|c|c|c|c|c|c|c|c|c|c|}
\hline \multirow{2}{*}{ Group } & \multirow{2}{*}{ Horses } & \multirow{2}{*}{$\begin{array}{c}\text { Age } \\
\text { (years) }\end{array}$} & \multirow{2}{*}{ Sex } & \multirow{2}{*}{ Colour } & \multirow{2}{*}{$\begin{array}{c}\text { Paddock } \\
\text { (h/day) }\end{array}$} & \multirow{2}{*}{$\begin{array}{l}\text { Walker } \\
\text { (min/day) }\end{array}$} & \multirow{2}{*}{ Shod } & \multicolumn{2}{|c|}{$\begin{array}{c}\text { Daily } \\
\text { intake (mg) }\end{array}$} \\
\hline & & & & & & & & $\mathrm{Zn}$ & $\mathrm{Cu}$ \\
\hline \multirow[t]{8}{*}{ Experimental } & 1 & 5 & Mare & Bay & 8 & - & Yes & 440 & 84 \\
\hline & 2 & 5 & Mare & Bay & - & 45 & Yes & 440 & 84 \\
\hline & 3 & 13 & Mare & Bay & - & 45 & - & 440 & 84 \\
\hline & 4 & 8 & Mare & Bay & 8 & - & Yes & 440 & 84 \\
\hline & 5 & 10 & Mare & White & - & 45 & Yes & 440 & 84 \\
\hline & 6 & 5 & Mare & Bay & 8 & - & Yes & 440 & 84 \\
\hline & 7 & 6 & Mare & Bay & 8 & - & - & 440 & 84 \\
\hline & 8 & 8 & Mare & Bay & - & 45 & Yes & 440 & 84 \\
\hline \multirow[t]{8}{*}{ Control } & 9 & 8 & Mare & Bay & 8 & - & Yes & 340 & 64 \\
\hline & 10 & 8 & Mare & Bay & 8 & - & - & 340 & 64 \\
\hline & 11 & 16 & Mare & Bay & 8 & - & - & 340 & 64 \\
\hline & 12 & 12 & Mare & Chestnut & 8 & - & - & 340 & 64 \\
\hline & 13 & 7 & Gelding & Chestnut & 8 & - & Yes & 340 & 64 \\
\hline & 14 & 18 & Mare & White & 8 & - & - & 340 & 64 \\
\hline & 15 & 19 & Mare & Bay & - & 45 & - & 340 & 64 \\
\hline & 16 & 8 & Mare & Bay & 8 & - & - & 340 & 64 \\
\hline
\end{tabular}


The experiment was conducted in line with regulations for experiments on animals. The results obtained were statistically evaluated using Student's t-test for paired samples. The initial values were statistically evaluated using Student's t-test for unpaired samples.

Table 2. Nutrient composition of basal feeding ration for all groups of horses

\begin{tabular}{lccc}
\hline \multicolumn{1}{c|}{ Parameter } & Meadow hay & Oat & Meal* \\
\hline Weight (g) & 1000 & 1000 & 1000 \\
Dry matter (g) & 960.80 & 966.70 & 971.65 \\
Crude fibre (g) & 319.21 & 102.20 & 42.30 \\
Crude fat (g) & 16.65 & 33.52 & 21.51 \\
Crude protein (g) & 93.26 & 131.48 & 139.87 \\
Ash (g) & 70.72 & 28.75 & 27.02 \\
Ca (g) & 4.22 & 1.37 & 1.01 \\
P (g) & 3.18 & 3.26 & 4.07 \\
Mg (g) & 1.34 & 1.01 & 1.37 \\
K (g) & 23.42 & 4.68 & 5.40 \\
Fe (mg) & 266.34 & 96.85 & 165.96 \\
Zn (mg) & 21.32 & 48.42 & 39.68 \\
Mn (mg) & 63.02 & 35.38 & 36.02 \\
Cu (mg) & 4.49 & 6.71 & 5.71 \\
\hline
\end{tabular}

$* 50 \%$ wheat meal, $50 \%$ barley meal.

Table 3 . The contents of substances in $1 \mathrm{~kg}$ of feed additive

\begin{tabular}{lll}
\hline \multicolumn{1}{c|}{ Composition } & Content \\
\hline Copper (mg) & 2000 \\
Zinc (mg) & 10000 \\
Biotin (mg) & 6000 \\
Pyridoxine (mg) & 1500 \\
Riboflavin (mg) & 2000 \\
Vit. B ${ }_{12}(\mathrm{mg})$ & 10 \\
Vit. D (IU) & 100000 \\
Methionine (g) & 200 \\
Glucose (g) & 100 \\
Butylhydroxytoluene (mg) & 25 \\
Butylhydroxyanisole (mg) & 5 \\
Ethoxyquin (mg) & 50 \\
\hline
\end{tabular}




\section{Results}

The initial amounts of individual elements in the samples of hoof horn and hair were compared with the final samples collected after nine months of experimental monitoring. The average initial and final level of monitored elements of skin derivatives, their standard deviations and statistical dependences are presented in Table 4. The initial sampling did not show any significant difference between the groups in any of the monitored parameters. The results show that the intervention in the feeding ration of horses resulted in a highly significant increase $(\mathrm{P}<0.01)$ of zinc content deposited in the dry matter of hoof horn. A significant difference $(\mathrm{P}<0.05)$ was detected also in the contents of copper and manganese, the amounts of which in the final sampling increased by $69.9 \%$ and $58.1 \%$, respectively. Differences in the contents of individual elements in the dry matter of hoof horn and mane hair of the control group were insignificant between the first and final samplings. We found a significant decrease $(\mathrm{P}<0.05)$ of manganese, iron and calcium content deposited in the dry matter of horse hair. The zinc and copper amounts in the mane of horses decreased only slightly after the addition of feed additive.

During the nine months of the experiment, the average rate of skin derivatives increment was monitored and evaluated (Table 5). Both cases exhibited a significant difference $(\mathrm{P}<0.01)$ between the two groups. The total increment of hoof horn in horses receiving the feed additive amounted to $71.50 \pm 6.66 \mathrm{~mm}$, being $22.3 \%$ higher than in the control group with a growth rate of $58.46 \pm 5.77 \mathrm{~mm}$. The growth rate difference after the first ten weeks and at the final measurement was $11.6 \%$ and $30.1 \%$, respectively. The total increment of hairs was $138.48 \pm 8.73 \mathrm{~mm}$ in horses of the experimental group and $120.02 \pm 10.83 \mathrm{~mm}$ in horses of the control group. The growth rate was relatively constant in both groups during monitoring (Fig. 1).

When comparing the initial and final samples, the horses deposited more elements into the horny tissue than into the structure of hairs. At a lower rate of hoof growth, the horses deposited a significantly higher amount of supplementary elements. The contents of supplemented elements in horse hairs remained unchanged; however, the amount of other elements significantly decreased due to the high growth rate of these derivatives.

Another measurement concerned the dependence of hair growth rate on the amount of microelements deposited in the mane. In the experimental group, the measure of mutual relation between the variables was not statistically significant in the microelement copper. Nevertheless, Fig. 2 suggests a decreasing amount of the deposited element with the increasing growth rate. A significant correlation was found for copper in the control group. In the experimental group, $1 \mathrm{~mm}$ growth rate increase resulted in a decrease of copper amount deposited in the dry matter of mane hair by $0.153 \mathrm{mg} \cdot \mathrm{kg}^{-1}$. In the control group, copper deposition decreased by $0.324 \mathrm{mg} \cdot \mathrm{kg}^{-1} \mathrm{DM}$ with each increasing millimetre. 


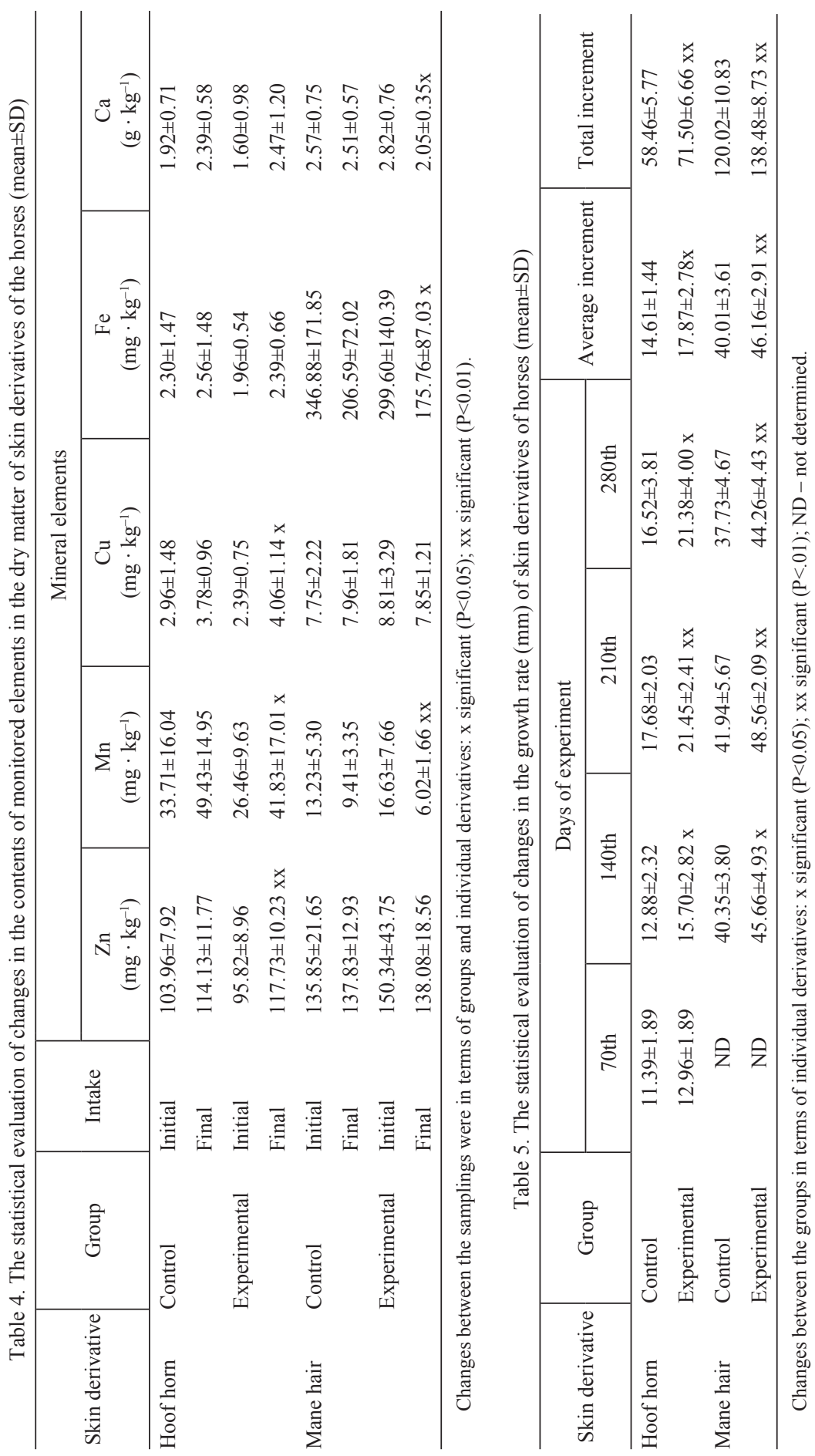




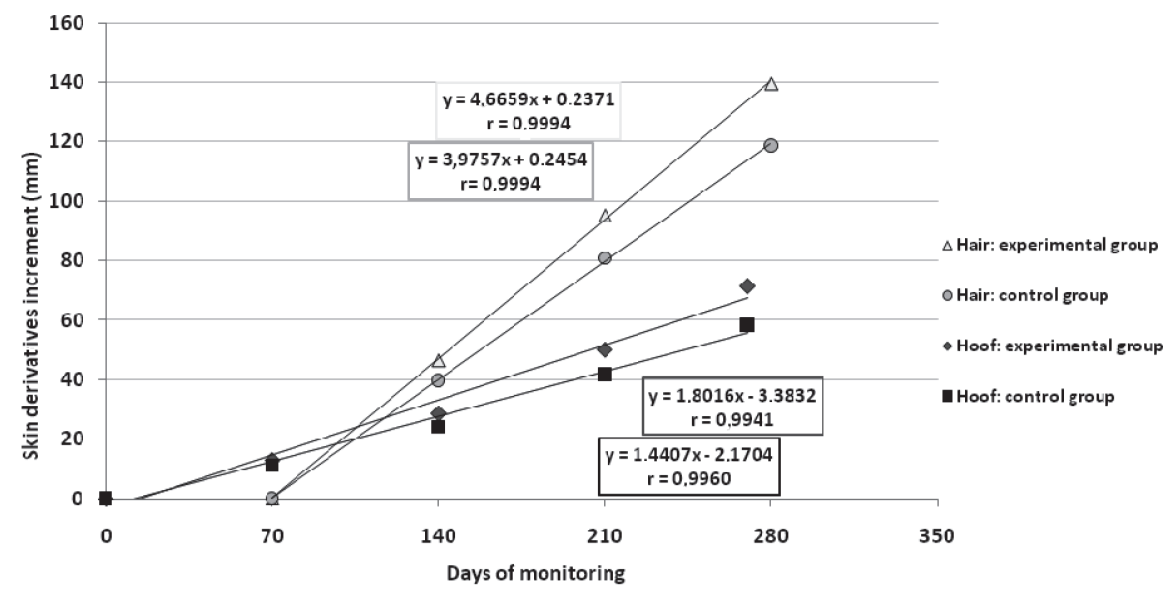

Fig. 1. Demonstration of the growth rate of skin derivatives during the monitored experimental periods and expression of their dependence

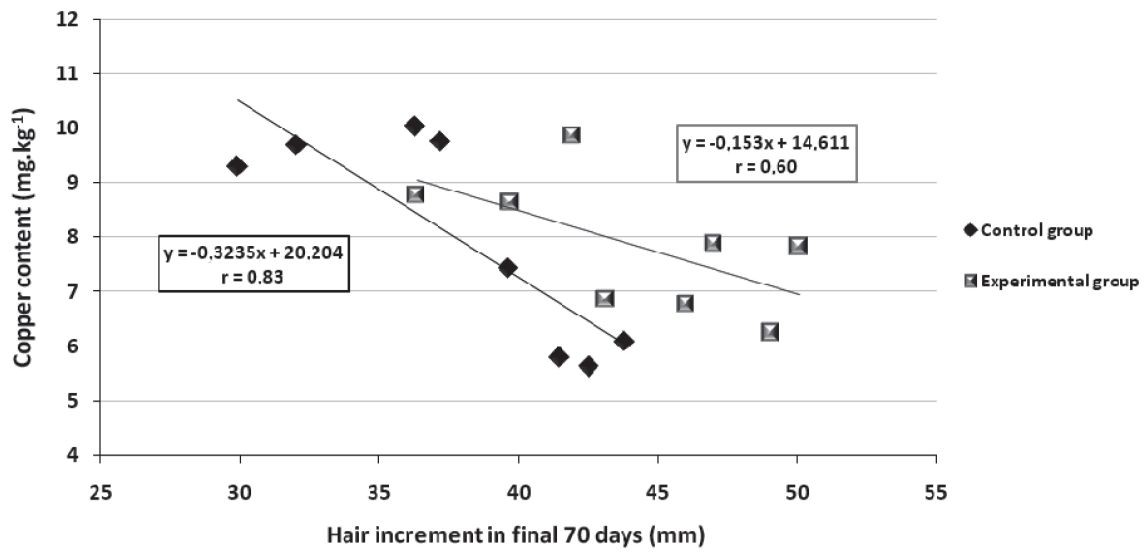

Fig. 2. Mutual relation between the hair growth rate and the amount of copper deposited in the dry matter of mane hair

\section{Discussion}

Nutritional factors play an important role in establishing the quality and integrity of the horny tissue within a genetically conditioned framework (Mülling, 2009).

Wichert et al. (2002) determined the contents of copper and zinc to be $7.2 \pm 4.1$ $\mathrm{mg} \cdot \mathrm{kg}^{-1}$ and $146 \pm 46 \mathrm{mg} \cdot \mathrm{kg}^{-1}$ of the dry matter (DM) in hoof horn. The authors report that horses with an occasional non-toxic excessive supply of copper and zinc 
could have been observed to show higher contents of these elements in the horn of hooves. A study performed by Coenen and Spitzlei (1997) demonstrated that horses with poor quality hooves showed a lower zinc level in the horn than horses with normal hooves. They demonstrated that the zinc amount in the horny tissue of hooves increased apparently after the addition of 300-500 $\mathrm{mg} \mathrm{Zn} /$ day.

Ott and Johnson (2001) studied the effect of mineral source on the growth of hooves in yearlings. The rate of growth was $4 \%$ higher in the group with the intake of zinc, manganese and copper in the form of proteinate when compared to the group supplied with the inorganic sources of these elements. Siciliano et al. (2001) conducted a similar experiment with adult mares. In their experiment, they did not find any differences in hoof growth capability, hardness and pulling force in mares whose daily requirement of manganese, zinc and copper was at $50 \%$ covered by organic sources of these elements. Clark and Rakes (1982) indicate that the addition of methionine hydroxy analogue led to an increase in the growth rate of cow hooves. Josseck et al. (1995) did not demonstrate any difference in the growth rate of the horny tissue between the two groups of which one received biotin and the other received placebo. Reilly et al. (1998) studied the effect of biotin addition at $0.12 \mathrm{mg} / \mathrm{kg}$ body weight on the growth rate of the hoof-wall in ponies. The growth rate of the hoof capsule in the control group without the addition of biotin was $30.69 \mathrm{~mm}$ after five months of monitoring. The treated group achieved $35.34 \mathrm{~mm}$ and thus reached a significantly $(\mathrm{P}<0.05)$ higher increment of hoof horn in the studied period. Butler and Hintz (1977) observed an increase of 50\% in the hoof growth rate in the group of ponies with the ad libitum intake of pelleted feeding ration than in the group with the limited feeding ration $(0.384 \pm 0.009$ vs. $0.254 \pm 0.008 \mathrm{~mm} /$ day, resp. $)$. The zinc amount in the hoof horny tissue of the group with the limited feeding reached $136 \pm 3 \mathrm{mg} \cdot \mathrm{kg}^{-1} \mathrm{DM}$ and was significantly higher $(\mathrm{P}<0.01)$ than in the ad libitum fed group (114 $\left.\pm 2 \mathrm{mg} \cdot \mathrm{kg}^{-1} \mathrm{DM}\right)$. Thus, the research shows a decreasing trend between the hoof-wall growth rate and the amount of zinc deposited in the hoof horn. A similar trend was observed in our experiment in the case of copper deposited in the mane hair (Fig. 2).

Horses receiving the feed additive achieved a significantly $(\mathrm{P}<0.01)$ faster growth of the hoof horn with an adequate quality of hooves in our experiment.

Despite the lack of scientific data to prove reliability, hair analysis has been advertised as a prognostic and diagnostic test for dietary mineral imbalances in horses (Wells et al., 1990). Mineral content of animal hair apparently varies not only with mineral intake, but also with the season (Biricik et al., 2005), breed, sex, age and hair colour (Wells et al., 1990). However, Asano et al. (2005) revealed no significant differences among males, females, and castrated horses, among breeds, or as a result of the age of the horses. No significant differences were found in the content of minerals between different hair colour and season in the present study.

Armelin et al. (2003) evaluated the effect of chelated mineral supplementation $(\mathrm{Cu}, \mathrm{Fe}, \mathrm{K}, \mathrm{Mg}, \mathrm{Mn}$ and $\mathrm{Zn})$ on the deposition in horse hair. There were significant differences $(\mathrm{P}<0.05)$ in $\mathrm{Fe}, \mathrm{K}$ and $\mathrm{Zn}$ concentrations between the samples suggesting that supplementation increases the absorption of these elements by the animal organism. However, it cannot be said that the increase in $\mathrm{Fe}, \mathrm{K}$ and $\mathrm{Zn}$ concentrations was 
due to Fe-glycine, K-glycine, Zn-glycine or the combination of these six mineral complexes that are part of the supplement. On the other hand, the supplementation had no significant effect on the $\mathrm{Cu}, \mathrm{Mg}$ and $\mathrm{Mn}$ concentrations in the horse hair.

Marycz et al. (2009) examined the correlation of elemental composition and morphological properties of the horses' hair after 110 days of feeding with high quality commercial food enriched with $\mathrm{Zn}$ and $\mathrm{Cu}$ organic forms. An average concentration of $\mathrm{Cu}, \mathrm{Zn}, \mathrm{S}, \mathrm{Si}, \mathrm{Mg}, \mathrm{Co}, \mathrm{Fe}$ and $\mathrm{P}$ in the examined hair of experimental horses before the research was lower than at the end of the supplementation programme. Our results demonstrated the opposite trend. At a higher growth rate of hairs, horses in the experimental group deposited lower amounts of monitored elements. In their experiment, the yearlings suffered from mild anaemia and underweight because the mineral intake was deficient before supplementation. Conversely in our experiment, the horses showed no signs of disease. It could have been the cause of differences in the results. Moreover, the exact intake of zinc and copper is not known and these authors only stated that yearlings received high doses of these elements. Horses in our experiment received adequate amounts of $\mathrm{Zn}$ and $\mathrm{Cu}$ according to NRC (2007). This fact can also cause different results.

Dunnett and Less (2003) reported that both mane and tail hair growth is relatively constant over a 12-month period. Growth rate was highest in cranial part of the manes and averaged $0.789 \mathrm{~mm} /$ day. Our results demonstrated a similar trend. The average daily mane increment in horses receiving the feed additive amounted to $0.663 \mathrm{~mm} /$ day.

Our experiment shows that the hair analysis is not a reliable diagnostic indicator for evaluation of mineral status in horses and the quality of skin derivatives. Assessing the impact of individual vitamins and trace elements, or the impact of various sources of trace elements on the growth rate and quality of skin derivatives should be subject to further observation.

\section{References}

A b d in - b e y M.R. (2007). Hoof quality: correlation between calcium, phosphorus, copper and zinc levels in the hoof shavings and blood levels of Arabian horses in Saudi Arabia. Sci. J. King Faisal University-Science, 8: 101-110.

Armelin M.J.A., Ávila R.L., P i a s e nt in R.M., S e iki M. (2003). Effect of chelated mineral supplementation on the absorption of $\mathrm{Cu}, \mathrm{Fe}, \mathrm{K}, \mathrm{Mn}$ and $\mathrm{Zn}$ in horse hair. J. Radioanal. Nucl. Ch., 258: 449-491.

A s a no K., Suzuki K., Chiba M., Sera K., A s a no R., S a kai T. (2005). Twenty-eight element concentrations in mane hair samples of adult riding horses determined by particle-induced X-ray emission. Biol. Trace Elem. Res., 107: 135-140.

B iricik H., Ocal N., Gucus A.I., Ediz B., Uzman M. (2005). Seasonal changes of some mineral status in mares. J. Equine Vet. Sci., 25: 346-348.

B utle r K.D., Hintz H.F. (1977). Effect of level of feed intake and gelatin supplementation on growth and quality of hoofs of ponies. J. Anim. Sci., 44: 257-261.

C lark A.K., R a kes A.H. (1982). Effect of methionine hydroxy analog supplementation on dairy cattle hoof growth and composition. J. Dairy Sci., 65: 1493-1502.

Coenen M., Spitzlei S. (1997). The composition of equine hoof horn with regard to its quality (hardness) and nutrient supply of horses. Proc. 15th ENPS Symposium, pp. 209-212. 
D un ne t t M., L e e s P. (2003). Trace element, toxin and drug elimination in hair with particular reference to the horse. Res. Vet. Sci., 75: 89-101.

J o s s e c k H., Z e n k e r W., G e ye r H. (1995). Hoof horn abnormalities in Lipizzaner horses and the effect of dietary biotin on macroscopic aspects of hoof horn quality. Equine Vet. J., 27: 175-182.

Marycz K., M o 11 E., Z a wa dzki W., Nic poń J. (2009). The correlation of elemental composition and morphological properties of the horses hair after 110 days of feeding with high quality commercial food enriched with $\mathrm{Zn}$ and $\mathrm{Cu}$ organic forms. EJPAU, 12, 04.

Mülling Ch.K.W. (2009). Nutritional influences on horn quality and health. WCDS Adv. Dairy Technol., 21: 283-291.

M ü 11 in g Ch.K.W., B u d r a s K.D. (1998). Der Interzellularkitt (Membrane Coating Material, MCM) in der Epidermis der Rinderklaue. Wien. Tierärztl. Mschr., 85: 216-223.

Müll ing Ch.K.W., B ragulla H.H., R e es e S., Budras K.D., S te in berg W. (1999). How structures in bovine hoof epidermis are influenced by nutritional factors. Anat. Histol. Embryol., 28: 103-108.

National Research Council (2007). Nutrient Requirements of Horses. 6. Washington, D. C.: The National Academies Press, $341 \mathrm{pp}$.

O t t E.A., J o h n s o n E.L. (2001). Effect of trace mineral proteinates on growth and skeletal and hoof development in yearling horses. J. Equine Vet. Sci., 21: 287-291.

Reilly J.D., Cottre 11 D.F., Martin R.J., Cuddeford D.J. (1998). Effect of supplementary dietary biotin on hoof growth and hoof growth rate in ponies: a controlled trial. Equine Vet. J., 26: $51-57$.

S i c il ia no P.D., Culley K.D., Engle T.E., S m ith C.W. (2001). Effect of trace mineral source (inorganic vs. organic) on hoof wall growth rate, hardness and tensile strength. Proc. 17th Equine Nutrition and Physiology Symposium, University of Kentucky, Lexington, USA, pp. 143-144.

Tenaud I., Leroy S., Chebassier N., Dreno B. (2000). Zinc, copper and manganese enhanced keratinocyte migration through a functional modulation of keratinocyte integrins. Exp. Dermatol., 9: 407-416.

Tomlins on D.J., Muelling CH.K.W., F a kler T.M. (2004). Formation of keratins in the bovine claw: roles of hormones, minerals, and vitamins in functional claw integrity. J. Dairy Sci., 87 : 797-809.

W a gner E.L., Potter G.D., Gibbs P.G., Elle r E.M., S cott B.D., Vogels ang M.M., W a 1 z e m R.L. (2010). Copper, zinc-superoxide dismutase activity in exercising horses fed two forms of trace mineral supplements. J. Equine Vet. Sci., 30: 31-37.

W e 11 s L.A., L e r o y R., R a 1 s t on S.L. (1990). Mineral intake and hair analysis of horses in Arizona. Equine Vet. Sci., 10: 412-416.

W i c hert B., Frank T., K i e n z le E. (2002). Zinc, copper and selenium intake and status of horses in Bavaria. J. Nutr., 132: 1776-1777.

Accepted for printing 12 I 2012

PETRA JANČÍKOVÁ, PAVEL HORKÝ, LADISLAV ZEMAN

\section{Wpływ dodatków paszowych zawierających witaminy i pierwiastki śladowe na profil pierwiastkowy i wzrost przydatków skóry koni}

\section{STRESZCZENIE}

Znaczenie suplementów diety odnośnie jakości i wzrostu przydatków skóry nie jest dostatecznie zbadane. Celem pracy było ustalenie, w jaki sposób podanie wybranych witamin oraz organicznej formy cynku i miedzi wpłynie na rozwój i jakość kopyt oraz włosów koni. Szesnaście gorącokrwistych koni podzielono na dwie grupy. Obie grupy karmiono taką samą dietą podstawową, którą dla grupy ekspe- 
rymentalnej wzbogacono o dodatek paszowy. W próbkach kopyt i włosów koni określono zawartość wybranych pierwiastków, przy użyciu atomowej spektrometrii absorpcyjnej.

Po dziewięciomiesięcznej obserwacji, w próbkach pobranych od koni w grupie eksperymentalnej, statystycznie istotnie wzrosła ilość cynku $(\mathrm{P}<0.01)$, miedzi i manganu $(\mathrm{P}<0.05)$ w rogu kopytowym oraz wyraźnie zmniejszyła się $(\mathrm{P}<0.05)$ ilość manganu, żelaza i wapnia zawartego we włosach grzywy. Różnice pomiędzy pierwszymi i ostatnimi próbkami przydatków w grupie kontrolnej były statystycznie nieistotne. Szybkość wzrostu włosa i ściany kopyta była większa $(\mathrm{P}<0.01) \mathrm{w}$ grupie eksperymentalnej w porównaniu z kontrolną. Konie, którym podawano dodatek paszowy miały kopyta odpowiedniej jakości. Badania wykazały, że włosy grzywy nie są wiarygodnym wskaźnikiem stanu odżywienia koni. Jednak ocena wpływu witamin i pierwiastków śladowych lub wpływu różnych źródeł pierwiastków śladowych na profil pierwiastkowy i tempo wzrostu przydatków skóry koni powinna być przedmiotem dalszych badań. 